\title{
Examining Malaysian Public Letters to Editor on COVID-19 Pandemic: A Corpus-assisted Discourse Analysis
}

\author{
Siti Aeisha Joharry ${ }^{a}$ \\ aeisha@uitm.edu.my \\ Universiti Teknologi MARA, \\ Shah Alam, Malaysia \\ Syamimi Turiman ${ }^{b}$ \\ syamimituriman@uitm.edu.my \\ Universiti Teknologi MARA, \\ Shah Alam, Malaysia
}

\begin{abstract}
Around the world, people are now facing an unprecedented situation with the COVID-19 virus pandemic. With numerous countries announcing various modes of self-quarantine and social distancing, the Malaysian government has initially called for a 3-week Movement Control Order (MCO) beginning mid-March 2020. In this paper, we explore how citizens in Malaysia respond to such crises by examining letters that were submitted during the MCO period to The Star Online the nation's leading English online news portal. Using corpus linguistics techniques, 227 letters were firstly investigated for recurrent words/phrases used on how people talk about issues during this time. A critical discourse analysis on these recurring patterns of language was then employed to further examine their occurrences in this corpus, following Carvalho's (2008) analysis of media discourse. This, we contend as being the synergy between corpus methods and classic CDA that contribute to the corpus-assisted discourse analysis (CADS) approach. Results yield Malaysians' view on the matter that could describe in so far as how the country is coping with the pandemic at the time. More specifically, letters that have mostly referred to COVID-19 pandemic as being a challenge and associating it with negative expressions are in fact emotionally charged, revealing how public letters written by citizen journalists provide a much more comprehensive view of public stance on COVID-19 in Malaysia.
\end{abstract}

Keywords: COVID-19; Movement Control Order (MCO); corpus-assisted discourse analysis (CADS); corpus linguistics; critical discourse analysis

\section{INTRODUCTION}

The recent COVID-19 outbreak has garnered much attention around the world - it is an unprecedented situation as countries can be seen reacting to this novel coronavirus (also coined as COVID-19, which means Coronavirus Disease 2019) in various ways. Such calamity has left many people feeling confused and uneasy as to what necessary steps should be taken next. In China for instance, an immediate lockdown was ordered in the province where the virus was firstly identified. Almost as soon as the news of the virus spread, there was not a place in the world that was not left afflicted -a total of 4,006,257 cases were reported as of 11th May 2020 (WHO, May

\footnotetext{
${ }^{a}$ Correspondent author
}

${ }^{b}$ Main author 
2020). Immediate actions can be seen from governments and in turn, generated many feedbacks from the society -often with a negative response, perhaps because of the sudden change of normalcy. One decision in particular is the instruction for self-isolation or quarantine. This is mainly due to numerous research that has shown the effectiveness of surveillance and containment measures against the spread of COVID-19 (e.g. Hellewell et al., 2020; Wilder-Smith \& Freedman, 2020).

In Malaysia, this measure is known as the Movement Control Order (MCO) -a form of community-wide containment as described by Wilder-Smith and Freedman (2020: p.2), which is "an intervention applied to an entire community, city or region, designed to reduce personal interactions, except for minimal interaction to ensure vital supplies". They further add that:

[i]t is a continuum to expand from social distancing to community-wide quarantine with major movement restrictions of everyone. Enforcement of community-wide containment measures is far more complex given the larger number of persons involved. [...] Implementation requires close partnerships and cooperation with law enforcement at the local and state level, and often involves checkpoints, and may need legal penalties if quarantine violations occur (p.2).

Given this community containment and the impact it has on individual liberty (especially freedom to move); it is not surprising that people have shown displeasure to this measure (Wilson, 2020). However, as research has shown, the public has an important role in controlling the spread of this virus, simply by breaking the chain of transmission and to 'stay at home' (e.g. Hellewell et al., 2020; Wilder-Smith \& Freedman, 2020). Fisher and Wilder-Smith (2020) argue that one of the important protocols during this crisis includes "fully engaging the public on the seriousness of, and their role in, the response [to COVID-19]" (p.1109). Malaysians particularly, have been reminded and reassured of the progress and development in this country by reports presented daily by the Director General of Health in Malaysia; Datuk Dr Noor Hisham Abdullah, who has repeatedly shown that the MCO has proven beneficial to stop the transmission of COVID-19. Even so, the government receives plenty of comments from the public, usually through the use of media channels. One of which is the public online letters to the editor of a newspaper agency. The emergence of 'citizen journalism' (McNair, 2009) is worth mentioning here, since it describes the circulation of public opinion, and to a certain extent influences the way the mainstream media covers important events such as COVID-19. According to Nguyen (2009), citizen journalism is able to generate significant changes in public life via a healthy public sphere, created by three elements that constantly interact with each other, namely journalism, social movements, and the discourses between citizens, experts and policymakers. The mainstream media carries the role of initiating an issue which will be "amplified via online citizen discussions, and then echoed back to the mainstream agenda" (p.160). This is where interest lies in exploring the Malaysian views on COVID-19 through a critical discourse analysis of online letters to the editor during the implementation of MCO, via corpus linguistics techniques. In other words, this paper highlights the significance of the corpus-assisted discourse analysis (CADS) that would be useful for this kind of study.

\section{BACKGROUND TO THE STUDY}

Research on COVID-19 has unsurprisingly risen mainly from medical studies trying to come up with a vaccine for this highly contagious disease. Others may have sparked interest on how the virus has impacted much of the socio-economic and education sectors around the world (Nicola et 
al., 2020; Burgess \& Sievertsen, 2020; United Nations, 2020). Recently, more reports have highlighted worrying side-effects of the coronavirus and its implications -particularly on certain groups of society (e.g. psychological effects - Azif Azuddin, 2020; Loheswar, 2020; domestic abuse - Arumugam, 2020; Hasimi Muhamad, 2020). As stated in their website, the United Nations (2020) has described the aftermath of this outbreak as affecting all segments of the population, particularly those social groups in the most vulnerable situations (i.e. older persons, persons with disabilities and people living in poverty situations). The health and economic impact are greater on the poor people, such as homeless people, refugees or migrants, due to factors such as limited movement, fewer employment opportunities, increased xenophobia and others. A study carried out by a team from King's College London on psychological impact of quarantine during previous disease outbreaks like SARS (severe acute respiratory syndrome) and others have shown that quarantine can produce a wide range of psychological effects, including post-traumatic stress symptoms, depression, feelings of confusion, anger and fear, and even substance misuse (Brooks et al., 2020).

In Malaysia, a number of cases have been reported (Arumugam, 2020; Hasimi Muhamad, 2020 \& Loheswar, 2020), namely issues pertaining to mental health risks, domestic violence and fraud/fake news leading to potential crimes that were ramifications of COVID-19, mainly as a result of the long period of MCO. In light of this, numerous research has been conducted to explore the impact of COVID-19 on the public, which include studies investigating social knowledge/perceptions related to the pandemic, often using survey as a typical method (e.g. knowledge/perceptions of healthcare workers in Bhagavathula et al., (2020). However, not much has been done on a linguistic perspective, although Singh et al. (2020) have examined how information and misinformation on COVID-19 is shared on Twitter. Thus, this has led to our interest in presenting a linguistic analysis of the online discourse that revolves around the pandemic crisis - particularly during the time of community-wide containment (i.e. the MCO). Specifically, this paper explores the Malaysian views on COVID-19 through a critical discourse analysis by investigating public online letters to the editor of a popular news portal in the country via corpus linguistics techniques. Research has shown that letters to editors in online newspapers are highly valued by their readership (Raeymaeckers, 2005), and they are usually read by more people than commentaries or opinion pieces (Hayek, Mayrl, \& Russmann, 2019). When the ordinary citizens are given a voice via their letters to the editor, the media also gains knowledge about the public agenda and issues that are of interest to the public, making letters to editors a specialised discourse worthy to be examined.

Gee (2011) notes that discourse analysis provides the opportunity to see how writers use language in addressing their readers, evoke particular feelings and attitudes within their audience, and construct ideologies in their writing. In analysing discourse, the context plays an important role. According to van Djik (2008), the context includes three main elements namely the setting, participants and communication events. These elements will assist in understanding how and why the discourse occurred, and "highlights the traces of cultural and ideological meaning" (Ramanathan \& Tan, 2015: p.57). More specifically, this type of discourse analysis led to the use of Critical Discourse Analysis (CDA), which focuses on investigating the role of language in societal and political processes.

CDA considers discourse as a social practice (Fairclough, 1997), and relates meaning in text to the social and ideological phenomena which are necessarily complex and in turn, requires a multi-methodical approach (Wodak \& Meyer, 2009). Many discourse studies have combined CDA with other types of language analysis such as corpus linguistics (CL) methods, especially in 
studying online discourse (e.g. Baker et al., 2008), with a view to capitalise on the strengths of the approaches and mitigate some of the potential drawbacks (Collins, 2019). Baker et al. (2008) suggest that using a corpus in discourse analysis creates a more objective CDA, and this type of research is usually referred to as corpus-assisted discourse analysis, or CADS (originally termed by Partington, 2004; 2006). In this paper however, following Baker et al. (2008) for the most part, we contend that both CDA and CL are used equally throughout the process in what Baker et al. consider as "methodological synergy" compared to CL merely 'assisting' CDA as previously implied in Partington. We further assert that in terms of theorizing and situating the context, which is pertinent for the text analysis in CDA studies (Baker et al., 2008), we present Carvalho's (2008) framework for analysing media discourse as our CDA component to approaching the texts, which will be explained under Methods. The term 'CADS', perhaps unavoidably, will be used in this paper to refer to the general corpus techniques employed throughout the paper. Hence, this study attempts to interpret the Malaysian letters to the editor of a local online newspaper as a specialised discourse on the COVID-19 pandemic through analysing them via the CADS (or CDA-CL synergy) approach, which will be explained next.

\section{METHODS}

To reiterate, the present research examines ways in which Malaysians view the recent happenings related to the COVID-19 pandemic through critically analysing discourse of online letters to the editor during the implementation of $\mathrm{MCO}$, via corpus linguistics techniques. As mentioned earlier, this means conducting a corpus-assisted discourse analysis (CADS) and in this section, the approach is explained in more detail. This study employs a CADS framework where methods can generally be divided into two main processes: 1) the corpus-driven approach, followed by a 2) critical discourse analysis (CDA). As part of the first process, a focused and specialised corpus was compiled during the MCO period that amounted to 227 total letters (133,195 total of words) to editors of The Star Online. The Star has been reported in the Digital News 2019 Report by Reuters Institute to be the number one English news source in Malaysia with 16\%, after Malaybased sources like TV3 news (34\%) and Astro Awani (16\%) (Zaharom Nain, 2019).

In this paper, the corpus of letters was selected from the day MCO began, which was on the 18th of March 2020 until 30th of April (6 weeks). At the time of writing, the MCO instruction was extended until $12^{\text {th }}$ May 2020. In addition, only letters written by Malaysians are chosen to ensure that analysis would be reflective of the Malaysian discourse. This means that nonMalaysians writing from overseas, or expatriates that live in Malaysia are thus discarded for further analysis. In other words, the intention to collect letters from this period of time is to look at how Malaysians view the MCO period and what they are going through during the COVID-19 crisis. In practice, this is where the CDA approach is considered to be situational as well as socioculturally contextualised (Fairclough, 1995). We can hypothesize that letters may mostly reflect issues surrounding the MCO specifically, and the pandemic at large.

WordSmith Tools 6.0 (Scott, 2012) is used to firstly extract frequency lists that show salient words/phrases in the corpus, which would be telling of the content or 'aboutness' of these letters. It is important to note that by 'salient' here, we mean to not only describe the wordlist in terms of frequency, but also coupling this with examination of how words are frequently distributed within texts -referred to as 'range', which provides information about the word's prominence (Burch \& Egbert, 2019). Range is represented by the number of texts each word occurred in (the maximum here being the total number of letters in the corpus). It is important to 
identify salient words as not simply being frequent, but also recurring consistently in lots of texts to determine its significant use. Initial observation reveals that there are 66 frequent words ${ }^{c}$ distributed consistently throughout more than $50 \%$ of the total number of letters in the corpus (see Table 1). This means that the list not only presents words mostly used by writers (frequency), but they also occur in a lot of texts/letters (range), indicating that they are noticeable and therefore, salient in the corpus. For example, 'COVID-19' is used $48 \%$ of the time and occurs about $78 \%$ across different letters. The identification of frequent words (or keywords) is a common starting point in a corpus research. However, in this paper, we did not make any comparisons between different parts of the corpus nor between any other existing corpus outside of this collection of letters and thus in turn, we demonstrate how use of 'range' is important to delineate the choice of words selected for further analysis.

\section{CDA WITHIN THE CADS PERSPECTIVE}

As part of the second process within CADS, this section describes the methods pertaining to the CDA aspect. In terms of analysing media discourse, Carvalho (2008) is deemed an appropriate and relevant paper here. She outlines that within this framework (see Figure 1), the linguist typically begins with a textual analysis: investigating the layout/structural organization of the text followed by identifying themes (referred to as 'objects'), people or 'actors' mentioned in the texts, as well as examining language, grammar and rhetoric. She further adds that discursive strategies would be the next important aspect to look at, followed by ideological standpoints that may surface from an in-depth analysis. Having completed this stage, Carvalho (2008) describes the second stage as a contextual analysis, comprising two means: 1) a comparative-synchronic and 2) historical-diachronic analysis, which is not the focus in this paper, but is discussed in the Discussion/Conclusion section.

\begin{tabular}{|l|}
\hline $\begin{array}{l}\text { I. Textual analysis } \\
\frac{\text { 1. Layout and structural organization }}{\text { 2. Objects }}\end{array}$ \\
$\frac{\text { 3. Actors }}{\text { 4. Language, grammar and rhetoric }}$ \\
$\frac{\text { 5. Discursive strategies }}{\text { 6. Ideological standpoints }}$ \\
$\frac{\text { II. Contextual analysis }}{\text { 1. Comparative-synchronic analysis }}$ \\
$\frac{\text { 2. Historical-diachronic analysis }}{\text { Source: Carvalho, } 2008 \text { (p.167) }}$ \\
\hline
\end{tabular}

FIGURE 1. Framework for Analysis of Media Discourse

The goal here is to show how CADS manages to do similar textual analysis as described above, on top of being empirical in selecting items as starting points of analysis (without fear of "cherry picking"). In another sense, corpus techniques were part of the textual analysis that facilitate the analysis of media discourse during this stage. More specifically, 'COVID-19' was

c This is after 2 words were discarded $(A P R ; 2020)$ which are clearly pointing to the date of the letters. 
found to be a salient term and therefore used as a focus in the analysis. This is not surprising since the texts consist of letters written during the pandemic and MCO period. Certain lexical items like 'Apr' and '2020' were picked up in the frequency list, but are omitted in the analysis, signalling the genre by which the corpus represents (i.e. these items refer to the date of the letters and thus, not interesting for analysis). The next section presents findings as underpinned by the CADS approach: beginning with corpus-driven results, followed by a critical analysis of the discourse according to Carvalho (2008).

\section{FINDINGS}

Table 1 presents a list of salient words in terms of frequency and consistency or range in the corpus. As explained earlier, there are 66 frequent words distributed consistently throughout more than $50 \%$ of the total number of letters in the corpus and the term 'COVID-19' ranked 22nd in the list, occurring $48 \%$ of the time and $78 \%$ across different letters. As shown in Table 1, these words can be further grouped into two main categories, namely functional and lexical types as presented in Table 2. By doing this, we have identified more grammatical (or functional) words occurring 53 times as opposed to 14 content-related words (i.e. lexical). Although lexical words point more to what the texts are mainly about -these words are related to the virus (e.g. COVID-19, health), MCO period (e.g. control, movement, order, time), and people (e.g. government, public), there is more interest in the way it is used by looking at the content words occurring with functional words (i.e. by viewing the words' collocation).

TABLE 1. Salient words in terms of frequency and consistency (range)

\begin{tabular}{cccccc}
\hline $\mathbf{N}$ & Word & Freq. & \% & Texts & \% \\
\hline 1 & to & 4755 & 3.57 & 227 & 100.00 \\
2 & the & 8009 & 6.01 & 227 & 100.00 \\
3 & of & 3727 & 2.80 & 227 & 100.00 \\
4 & and & 4086 & 3.07 & 227 & 100.00 \\
5 & in & 2418 & 1.82 & 226 & 99.56 \\
6 & for & 1596 & 1.20 & 224 & 98.68 \\
7 & a & 2151 & 1.61 & 224 & 98.68 \\
8 & is & 1761 & 1.32 & 223 & 98.24 \\
9 & are & 1261 & 0.95 & 220 & 96.92 \\
10 & be & 1267 & 0.95 & 217 & 95.59 \\
11 & that & 1411 & 1.06 & 216 & 95.15 \\
12 & this & 1021 & 0.77 & 214 & 94.27 \\
13 & as & 1067 & 0.80 & 213 & 93.83 \\
14 & with & 882 & 0.66 & 208 & 91.63 \\
15 & on & 852 & 0.64 & 207 & 91.19 \\
16 & not & 819 & 0.61 & 206 & 90.75 \\
17 & have & 830 & 0.62 & 206 & 90.75 \\
18 & it & 785 & 0.59 & 204 & 89.87 \\
19 & by & 643 & 0.48 & 195 & 85.90 \\
20 & from & 607 & 0.46 & 193 & 85.02 \\
21 & we & 1066 & 0.80 & 191 & 84.14 \\
22 & COVID-19 & 645 & 0.48 & 177 & 77.97 \\
23 & their & 649 & 0.49 & 175 & 77.09 \\
24 & at & 551 & 0.41 & 175 & 77.09 \\
\hline
\end{tabular}




\begin{tabular}{|c|c|c|c|c|c|}
\hline 25 & has & 461 & 0.35 & 173 & 76.21 \\
\hline 26 & will & 661 & 0.50 & 171 & 75.33 \\
\hline 27 & can & 479 & 0.36 & 168 & 74.01 \\
\hline 28 & or & 602 & 0.45 & 166 & 73.13 \\
\hline 29 & all & 425 & 0.32 & 162 & 71.37 \\
\hline 30 & our & 589 & 0.44 & 160 & 70.48 \\
\hline 31 & also & 359 & 0.27 & 160 & 70.48 \\
\hline 32 & who & 356 & 0.27 & 157 & 69.16 \\
\hline 33 & control & 229 & 0.17 & 155 & 68.28 \\
\hline 34 & an & 397 & 0.30 & 155 & 68.28 \\
\hline 35 & more & 365 & 0.27 & 152 & 66.96 \\
\hline 36 & order & 200 & 0.15 & 151 & 66.52 \\
\hline 37 & but & 370 & 0.28 & 151 & 66.52 \\
\hline 38 & they & 420 & 0.32 & 149 & 65.64 \\
\hline 39 & movement & 189 & 0.14 & 148 & 65.20 \\
\hline 40 & should & 388 & 0.29 & 147 & 64.76 \\
\hline 41 & if & 349 & 0.26 & 147 & 64.76 \\
\hline 42 & these & 348 & 0.26 & 146 & 64.32 \\
\hline 43 & there & 319 & 0.24 & 141 & 62.11 \\
\hline 44 & many & 284 & 0.21 & 141 & 62.11 \\
\hline 45 & time & 274 & 0.21 & 137 & 60.35 \\
\hline 46 & other & 236 & 0.18 & 137 & 60.35 \\
\hline 47 & been & 294 & 0.22 & 137 & 60.35 \\
\hline 48 & health & 428 & 0.32 & 135 & 59.47 \\
\hline 49 & some & 247 & 0.19 & 134 & 59.03 \\
\hline 50 & government & 413 & 0.31 & 131 & 57.71 \\
\hline 51 & when & 261 & 0.20 & 130 & 57.27 \\
\hline 52 & which & 251 & 0.19 & 129 & 56.83 \\
\hline 53 & need & 309 & 0.23 & 128 & 56.39 \\
\hline 54 & $\mathrm{MCO}$ & 382 & 0.29 & 128 & 56.39 \\
\hline 55 & one & 225 & 0.17 & 127 & 55.95 \\
\hline 56 & would & 312 & 0.23 & 126 & 55.51 \\
\hline 57 & Malaysia & 279 & 0.21 & 122 & 53.74 \\
\hline 58 & out & 220 & 0.17 & 120 & 52.86 \\
\hline 59 & only & 215 & 0.16 & 120 & 52.86 \\
\hline 60 & such & 235 & 0.18 & 119 & 52.42 \\
\hline 61 & do & 251 & 0.19 & 119 & 52.42 \\
\hline 62 & us & 252 & 0.19 & 118 & 51.98 \\
\hline 63 & public & 255 & 0.19 & 115 & 50.66 \\
\hline 64 & even & 220 & 0.17 & 115 & 50.66 \\
\hline 65 & like & 187 & 0.14 & 114 & 50.22 \\
\hline 66 & during & 239 & 0.18 & 114 & 50.22 \\
\hline
\end{tabular}

TABLE 2. Categories of salient words

\footnotetext{
Functional to, the, of, and, in, for, a, is, are, be, that, this, as, with, on, not, have, it, by, from, we, their, at, has, will, can, or, all, our, also, who, an, more, but, they, should, if, these, there, many, other, been, some, when, which, need, would, only, do, us, even, like, during
} 

public, like $\mathrm{d}^{\mathrm{d}}$

This section continues to focus on the use of 'COVID-19' as a significant and relevant term that was shown to be both frequent as well as widely spread in the corpus. Further examination of co-occurring words surrounding how the virus was talked about was carried out via collocational analysis. Two statistical measures (t-score and Mutual Information) were used to determine which words were considered to be significant "partners" (collocates) to 'COVID-19', particularly those occurring immediately to the right of the key word. This means that the 'COVID-19+X' construction can be further examined. Table 3 shows 13 collocates that are both frequently and strongly associated with 'COVID-19', thus revealing common patterns of the word's cooccurrences. It is useful to note that different statistical measures score different things and so tscore is mainly used to measure frequency (values above 2) while values above 3 for MI refer to strength in association (Hunston, 2002) between words co-occurring in a span of usually five words on either side of the word under investigation (the node) (see Sinclair, 1991).

The first thing we can gather from Table 3 is that most significant collocates point to the 'COVID-19 + NOUN' word construction. 'COVID-19' is mostly used as an adjective describing a noun such as in COVID-19 pandemic/outbreak/cases and others, except for the use of does. With the collocate does, 'COVID-19' acts as a noun or a subject here; in instances like COVID-19 does not discriminate [...]. Further observation of the nouns following the adjective 'COVID-19' shows negative connotations like pandemic; outbreak; crisis; infection(s); virus; and epidemic. Other collocates such as cases, patient(s), and testing seem to describe the virus in terms of the number of statistics on incidences as well as referring to people afflicted with the disease and their medical treatment/intervention. Interestingly, law and does show to be significant collocates of 'COVID19 ' too -suggesting that there is talk about a potential COVID-19 law arising from this crisis while the phrase COVID-19 does not discriminate... reflects a type of figurative language used to personify the virus as afflicting many people, regardless of age, gender, religion nor ethnic background.

TABLE 3. Collocates for 'COVID-19' appearing immediately to the right

\begin{tabular}{lcc}
\hline Collocate/ raw score in brackets & t-score & MI value \\
\hline pandemic (68) & 8.1 & 5.9 \\
outbreak (32) & 5.6 & 6.4 \\
cases (29) & 5.2 & 5.2 \\
crisis (22) & 4.5 & 4.7 \\
patients (17) & 4.0 & 5.1 \\
law (10) & 3.1 & 4.9 \\
patient (9) & 2.9 & 6.2 \\
infection (9) & 2.9 & 4.7 \\
virus (7) & 2.4 & 3.5 \\
epidemic (6) & 2.4 & 5.3 \\
infections (6) & 2.4 & 5.3 \\
testing (6) & 2.3 & 3.9 \\
does (5) & 2.1 & 3.9 \\
\hline
\end{tabular}

\footnotetext{
d 'like' is double-classified under both word forms (grammatical and lexical) for its ambiguity in language use (I like xyz; other items like $x, y$ and $z$ )
} 
However, upon closer inspection, COVID-19 law was found to be over-used in only one letter' that specifically highlighted benefits of a proposed 'COVID-19 law' to help with issues related to economic problems arising from the pandemic. Since the ten occurrences were found to be lumped in one letter, this illustrates reasons for the strength of association between the two words -the term is highly specific given the context in which it occurred in. Meanwhile, the phrase COVID-19 does only occurs in 5 sentences; 4 of which show use of the figure of speech (idioms). As Stubbs (2002: p.220) notes, "[t]he most frequent uses, especially in journalism, are metaphorical (e.g. jobs face the axe; plans to axe jobs)". He adds that "collocate pairs with the strongest attraction are many fixed phrases, including idioms..." (p.224). Hence, the use of COVID-19 here (although a few) describes an idiomatic expression that in turn, also illustrates the strength of association between these words.

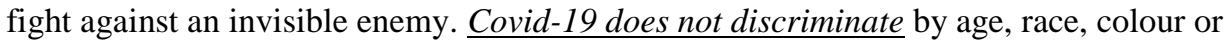
-economic inequalities. While Covid-19 does not discriminate who it infects, the rich good of all Malaysians. Remember, Covid-19 does not discriminate. The virus does not for us to remind ourselves as Covid-19 does not discriminate, our response should not

In the next part of this paper, closer inspection of salient phrasal patterns on the word 'COVID-19' is then carried out by investigating concordance lines. This is done by using the same software that extracts lines where the search term is positioned in the middle and surrounded by co-text that enables linguists to examine their use in context (see figure 2 below).

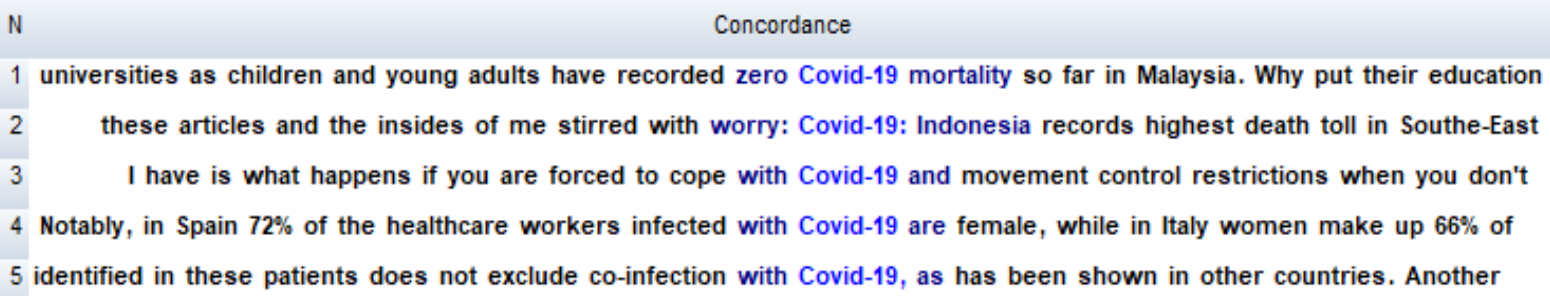

FIGURE 2. Example of concordance lines

This in turn, becomes the qualitative part of the study where a critical analysis of the discourse is made more possible. As Baker et al., (2008) similarly note, the above "CL techniques provide a 'map' of the corpus, pinpointing areas of interest for a subsequent close analysis" (p.284). They further add that the identification of lexical patterns thus leads to the examination of concordance lines, or when needed, the examination of fuller/whole texts. For reasons of space, this paper will examine the phrase 'COVID-19 pandemic', which is considered to be the most significant pattern, more closely. It is important to note that the COVID-19 pandemic is also referred to as the 'coronavirus pandemic', but only in 7 occurrences. So the name 'coronavirus' in this sense is not found as frequent when referring to the pandemic, at least not in the corpus.

PHRASEOLOGY -EXAMINING COVID-19 DISCOURSE

\footnotetext{
e Source: 11th April_Malaysia needs to enact a Covid-19 law to help the economy to recover
} 
As mentioned previously, CDA is carried out through use of concordancing, which is the qualitative side to corpus linguistics techniques. Further sorting (using the 'cluster' feature in WordSmith Tools) of 68 concordance lines with 'COVID-19 pandemic' reveals that certain phraseological combinations come up as being quite frequent. These include 3-word combinations this COVID-19 pandemic (6), COVID-19 pandemic is (5); 4-word combinations of the COVID-19 pandemic (10), by the COVID-19 pandemic (6), to the COVID-19 pandemic (6), the COVID-19 pandemic in (5), with the COVID-19 pandemic (5); and a 6-word combination from April till COVID-19 pandemic ends (5). This part of the findings will firstly report on the various phraseological patterns, classifying them in terms of similar meanings/evaluations and thematic views (e.g. Malaysians' positive/negative reactions towards COVID-19, impacts, struggles and coping strategies, and so on). The discussion is then followed by CDA following Carvalho (2008) under the section: Media discourse of COVID-19 letters to editor.

The 6-word combination 'from April till COVID-19 pandemic ends' was found to occur in one text by Dr Rais Hussin (26th March 2020) on what he calls a 'mercy-for-all stimulus' to resolve the economy post-COVID-19. It is important to remember here that findings are a result of corpus methods such as the identification of multi-word combinations via 'cluster' feature and in turn, results pointing to evidence of language use in a single text though can be arguable in terms of representativeness, remain to be interesting for analysis. The frequent combination is a prepositional phrase used to indicate the time-frame of suggested incentives and allowances, which could be paid to front liners, specifically from April until the pandemic ends. As a Parti Pribumi Bersatu Malaysia representative, this is interesting for further analysis on the discursive strategies found within this single text (as shown below) and how it illustrates the author's political standing/leaning, which in turn, can inform us of the ideological standpoints in his discourse.

Some of the suggestions for the administration to make: [...]

For Our Front-liners:

- Critical Services Incentive Payment (Bayaran Insentif Perkhidmatan Kritikal) to be increased from RM750 to RM1,000 from April until the pandemic ends.

- RM500 monthly allowance for medical doctors, nurses and medical personnel who are working tirelessly in hospitals and clinics from April till Covid-19 pandemic ends. (Sarawak Model)

- RM500 monthly allowance for Immigration officers manning the entry points throughout Malaysia from April till Covid-19 pandemic ends. (Sarawak model)

- RM500 monthly allowance for PDRM and officers working around the clock to ensure safety and security of Malaysians from April till Covid-19 pandemic ends. (Sarawak Model)

- RM500 monthly allowance for Malaysian Armed Forces (ATM) personnel manning the borders and those helping the police in maintaining law and order from April till Covid-19 pandemic ends. (Sarawak Model)

- Free food: Providing dedicated support of food supplies for doctors and healthcare personnel involved in the testing, diagnosing, and treating patients at risk of Covid19 from April till Covid-19 pandemic ends.

The expected economic stimulus to be presented by the administration will definitely be huge, although it will be implemented for a limited period of time, between six and 12 months. But because the nature of this stimulus lies in its focus and emphasis on putting money into the pockets of the most vulnerable segments of our society during the pandemic, it radiates and begets another mercy - the multiplier effect of their spending will revive the infected economy. The focus is to survive and get ready for a re-start of the economy. 
Dr Rais Hussin

Parti Pribumi Bersatu Malaysia strategist

As Baker et al. (2008) explain, "[f]or CDA, language is not powerful on its own - it gains power by the use people make of it and by the people who have access to language means and public fora" (p.280). They continue to argue that "[p]ower is signalled not only by grammatical forms within a text, but also by a person's control of a social occasion, by means of the genre of a text, or by access to certain public spheres" (p.280) and this can be found by Dr Rais Hussin's role in the Parti as a "strategist" - his views may not only be his own, but that of representing the Parti. The author wrote: "our suggestion is for the government to draw on some of its reserve to finance the big expenditures to save lives and re-start the economy" that describes his opinion, which also represents the Parti's opinion at the time, given the reflexive personal pronoun 'our'.

\section{MALAYSIANS' POSITIVE AND NEGATIVE REACTIONS TOWARDS COVID-19}

This section presents a close reading on the concordance lines with 3-word combinations, which are; this COVID-19 pandemic (6) and COVID-19 pandemic is (5) that revealed how 'COVID-19 pandemic' was discussed to convey positive hopes/messages. These can be seen in lines 1 and 2; to emphasise pre-emptive measures to contain the spread of COVID-19 via physical distancing (line 4); and to highlight on the government's role in managing the pandemic (in lines 3, 5 and 6).

(1) we hope that during this Covid-19 pandemic, we will choose to stand in solidarity

(2) positive messaging during this Covid-19 pandemic. Things in Malaysia have escalated

(3) to contain the negative impacts of this Covid-19 pandemic. Prudent use of power by the

(4) need for physical distancing during this Covid-19 pandemic. Places of detention are

(5) government setting during this Covid-19 pandemic, our Health Ministry recently agreed

(6) management and control of this Covid-19 pandemic. In the meantime, there must be care

Other than that, 'COVID-19 pandemic' occurs in other contexts such as to describe its impact on different levels, like the healthcare sector (lines 7 and 8) and property sector (line 10); and to illustrate the 'severity' of the pandemic as 'sweeping across the world at breakneck speed' (line 9) and 'World War III in a different sense' (line 11). These display uses of figurative expressions that highlight the range of style in which writers describe the spread of COVID-19.

(7) and public health specialists. The Covid-19 pandemic is affecting Malaysia medically

(8) syndrome) and H1N1 influenza. The Covid-19 pandemic is simply a stark reminder of

(9) 29 Mar 2020). The Covid-19 pandemic is sweeping across the world at breakneck speed

(10) with these properties when the Covid-19 pandemic is over. There are hundreds of

(11) (Monday, 23 Mar 2020). The Covid-19 pandemic is World War III in a different sense.

In addition, it was also discovered that Malaysians perceived COVID-19 pandemic as a cause for adversity, challenges, extraordinary situations, circumstances and even economic collapse, mainly through use of the passive form 'by' (lines 12-16). This function is similar to the use of the phrase 'due to the COVID-19 pandemic', which occurs 4 times -particularly pointing to the (global) recession, global shutdown, and even a ban on exporting masks to reserve them for certain countries' own use (lines 19-21). Lines 20 and 21 particularly incorporate the use of 'due 
to the COVID-19 pandemic' followed by the preposition in. This further situates the virus to the economic crisis and how the recession was declared by the International Monetary Fund (IMF) in January 2020.

(12) that are adversely affected by the Covid-19 pandemic. While we are observing the MCO

(13) other challenges are being eclipsed by the Covid-19 pandemic. While the impact of these

(14) extraordinary situation brought about by the Covid-19 pandemic, the government has no

(15) circumstances created by the Covid-19 pandemic have compounded gender inequality,

(16) the sudden economic collapse caused by the Covid-19 pandemic. Globally, businesses

(17) do more to help Malaysians affected by the Covid-19 pandemic. Do what is necessary

(18) today's recession is solely due to the Covid-19 pandemic. What is the worst economic

(19) Malaysia's private clinics. Due to the Covid-19 pandemic, Thailand, Taiwan, Korea and

(20) (IMF) declared a global recession due to the Covid-19 pandemic in January 2020. The

(21) to the global shutdown due to the Covid-19 pandemic in terms of the economic impact

These 3-word and 4-word combinations show how 'COVID-19 pandemic' co-occurs frequently with certain words or phrases that may signal evaluative meaning or provide a "sketch of the meaning/function of the node within the particular discourse" (Baker et al., 2008: p.278). In other words, these patterns demonstrate the speaker or writer's attitude or stance towards, viewpoint or feelings about COVID-19, which reveals writers' expressions towards the pandemic as either good or bad. This in turn highlights how COVID-19 discourse in online letters to the editor can be seen as persuasive and used to communicate to an audience shared values (for solidarity purposes).

\section{IMPACT, STRUGGLES AND COPING WITH COVID-19}

Other than expressing their emotions/concerns towards COVID-19, Malaysians also talk about the impacts, struggles and actions related to the 'COVID-19 pandemic', especially how citizens and countries have been reacting to the phenomena. This is shown in lines (22-30). Instances include the phrase to be co-occurring with heavily negative words/expressions like 'struggle to deal', 'taking a foothold', 'grapples', 'bleak news', 'long haul', and 'fight to contain'. This further adds to the negative evaluation of COVID-19 pandemic in texts.

(22) many countries struggle to deal with the Covid-19 pandemic, this step represents a

(23) may not happen in the near future with the Covid-19 pandemic taking a foothold in many

(24) (25 Apr 2020) As the world grapples with the Covid-19 pandemic, health experts are

(25) can generate any profit. Now, with the Covid-19 pandemic and with bleak news

(26) that we were in for the long haul with the Covid-19 pandemic. Although trials have

(27) an important role in helping to keep the Covid-19 pandemic in control. Our blessings to

(28) commendable job in the fight to contain the Covid-19 pandemic in our country. Our

(29) medical students can respond to the Covid-19 pandemic (Tuesday, 21 Apr 2020) Screen

(30) Malaysian government in response to the Covid-19 pandemic. This was followed by

Malaysians also write to the editor to describe the impact of COVID-19 on different levels, like the healthcare sector (lines 31 and 32) and property sector (line 33). 
(31) and public health specialists. The Covid-19 pandemic is affecting Malaysia medically (32) syndrome) and H1N1 influenza. The Covid-19 pandemic is simply a stark reminder of (33) with these properties when the Covid-19 pandemic is over. There are hundreds of

Meanwhile, the use of 'COVID-19 pandemic' which occurred in a longer string of words, namely of the COVID-19 pandemic has revealed interesting use of the different structural phrases to convey different meanings. One obvious meaning is the impact of the virus; particularly how COVID-19 pandemic has a strong/marked effect or influence on someone or something, which leads for certain consequences to happen. This is found in occurrences where the phrase co-occurs mostly with the words 'impact' and 'result' (lines 34-36). It can also be seen that the idiomatic expression 'in light of' is used to bring about the same meaning (lines 37, 38) - i.e. considering the pandemic, something is anticipated to occur/have occurred. This is shown in the following lines:

(34) 3.1bil to help SMEs counter the impact of the Covid-19 pandemic. The funds are being

(35) (Tuesday, 31 Mar 2020). The impacts of the Covid-19 pandemic in some respects are

(36) recession was imminent as a result of the Covid-19 pandemic. Many economists have

(37) correct facts on the disease. In light of the Covid-19 pandemic, many educational

(38) cases Wednesday, 15 Apr 2020 In light of the Covid-19 pandemic, it is prudent to

(39) management in the community. One legacy of the Covid-19 pandemic should be that we continue

The last example shows how the word 'legacy' is used to describe the pandemic. Line (29) refers to the impact/effects/aftermath of the pandemic, signalled by the use of 'legacy'. 'Legacy' is often used in terms of a person's inheritance or something left or handed down by a predecessor. Often to signal a positive connotation rather than a negative one, the use of 'legacy' here in reference to the virus creates a more positive evaluation of the pandemic from the writer, i.e. motivating/encouraging the health workforce especially, to improve their quality of work. Below is the line presented with more context:

One legacy of the Covid-19 pandemic should be that we continue to innovate, realising the benefits of being able to deliver functions of healthcare remotely or with more efficiency than previously. In the post Covid-19 era, the value of a health workforce that is able to respond in a resilient manner to population health challenges will be more apparent than ever. If the healthcare system is to be more innovative and integrated into the community, both system and human factors must be ready.

\section{WINNIE ONG}

Registered pharmacist

Kuala Lumpur

Finally, the 3-word combination 'Covid-19 pandemic' was used to illustrate the 'severity' of the pandemic as 'sweeping across the world at breakneck speed' (line 40) and 'World War III in a different sense' (line 41). These display uses of figurative expressions that highlight the range of style in which writers describe the spread of COVID-19.

(40) 29 Mar 2020). The Covid-19 pandemic is sweeping across the world at breakneck speed 
(41) (Monday, 23 Mar 2020). The Covid-19 pandemic is World War III in a different sense.

In these examples, the verb is that succeeds 'COVID-19 pandemic' simply describes the state of being of the pandemic. In other words, 'is' that co-occurs with 'COVID-19 pandemic' is able to situate the pandemic to the specific MCO period - the first 6 weeks of community-wide containment - that particularly refers to the writers' description of the pandemic during that point of time.

\section{MEDIA DISCOURSE OF COVID-19 LETTERS TO EDITOR}

Following Carvalho's (2008) framework on media discourse analysis (refer Figure 1), this section further analyses the instances mentioned in the previous section for critically analysing media discourse on COVID-19 letters to editors. In terms of layout and structural organisation, we argue that the texts belong to a certain register; one that is specialised in terms of online letters to the editors and in turn, some of the recurrent appearances of the salient term 'COVID-19' were found in the title of these letters as well as the first few lines of the letter, signalling what Carvalho deems as important to readers' selection of preferred reading (e.g. titles like 'Life transformed by Covid19', 'Stop the spread of Covid-19' and lines at the beginning of letters like 'We are now experiencing an exponential rise in confirmed Covid-19 cases', and 'Are we winning the battle against Covid-19?'). It is also interesting to find how bullet forms that were discovered through repeated multi-word combination 'from April till COVID-19 pandemic ends' used in letters like Dr Rais Hussin's help to structure his suggestions for the Stimulus Package that would focus readers' attention to them.

Next, we can argue that 'objects', which Carvalho associates with topics or themes were clearly described in terms of the collocational analysis presented earlier. We have seen how 'COVID-19' frequently and strongly co-occurs with objects related to not only health in general (e.g. cases, patients, infection), but we also found that it occurred with other objects like 'law' and the action verb 'does' in specific texts, revealing a metaphorical use of the term in 'COVID-19 does not discriminate' that further personalizes these letters. 'COVID-19' is referred to as an "actor" in some cases where letters describe what the virus does or is. The specific phrase of 'COVID-19 does not discriminate' gives the virus a sense of animated/personalised feature, which could be used to further argue for the rhetorical use of language in texts. Other actors being addressed include the community/society, medical (or other) frontliners, SMEs, governments and others, which allowed for specific interpretation to be made with regard to some or individual letters (note the ones by Dr. Rais Hussin and Winnie Ong).

In terms of stylistics, we can definitely see instances of figurative language being used in certain letters like personification of the virus (COVID-19 does not discriminate) and the metaphorical use of 'legacy' to imply the lesson brought about by this crisis in a more positive light. Overall, frequent collocates of 'COVID-19' denote negative portrayals of the virus (pandemic, outbreak) that are further emphasised with other negative connotative words upon further analyses of concordance lines (e.g. 'struggle to deal', 'taking a foothold'), while others talk mostly on the impact of the virus on economic issues (e.g. 'economic collapse', 'global recession/shutdown'). As Carvalho notes, "[a]n emotionally charged discourse, with an appeal to readers' emotions, for instance, is often found in the press, and can have an important rhetorical role" (2008: p.169). 
The repetition and similarities that we have found especially in terms of the interchangeable use as well as word associations of both salient phrases 'COVID-19 pandemic' and 'COVID-19 outbreak' generate certain strategies that may be recursive in normalizing certain subjectivities and exclude others (Faucoult, 1977). In this case, the use of both phrases reflect how people think/talk about the virus, specifically during the MCO period. More importantly, the crisis has been reported to have caused much disruption among Malaysians and majority of these letters express negative evaluations of the COVID-19 pandemic/outbreak. While not representing the whole corpus of letters, further in-depth analysis of Dr Rais Hussin's letter in particular has shown ideological standpoints that surfaced from the repeated 6-word combination "from April till COVID-19 pandemic ends' in his letter. In this regard, we can describe it as a form of "cohesion by reiteration" (Halliday \& Hasan, 1976: p.319) where concepts, as well as words are repeatedly used in a text to show discursiveness. The stimulus Dr Rais Hussin proposed in his letter to help resolve the economic troubles post-COVID 19 indirectly reflects his role in the Parti Pribumi Bersatu Malaysia, which is a nationalist political party that may be interesting for future study. ${ }^{\mathrm{f}}$

With respect to analysing large amounts of texts (compared to the traditional CDA), Carvalho (2008, p.173) suggests "to analyse some periods exhaustively and then focus on 'critical discourse moments', which seems a more adequate option than random sampling or an arbitrary form of choice of texts". This has been our decision to select texts during the MCO period that enabled us to closely zoom in on certain aspects of discourse that were illuminating given the specific time/context. At the time of writing, these letters were purposely collected during the first 6-week initial stage of the MCO in Malaysia and hence, we can safely argue that it is specialised in a sense. Although in the methodology we highlighted that the two sub-categories under Carvalho's contextual analysis was not fulfilled in the present study, the fact that the specialised corpus consisted Malaysian writers' letters to the editor during the MCO period is indicative of what Carvalho defines a comparative-synchronic analysis, i.e. "looking at various representations of an issue at the time of the writing of one specific news text (the unit of analysis)" (Carvalho, 2008: p.171), which in this case is COVID-19. And so, echoing from her: "[ $\mathrm{t}$ ]he analysis of those 'moments' allows for the identification of discursive turns and/or continued lines of argumentation at particularly important times in the social construction of an issue" (p.173), which we have found to be particularly useful when investigating Malaysian perceptions of COVID-19 in online letters to the editor and contending that it is highly contextualised.

\section{DISCUSSION/CONCLUSION}

For the most part, this paper has described opinion letters written by Malaysians during the instruction of community-wide containment period. More specifically, letters were written mostly about COVID-19 especially in relation to it as seen as a 'pandemic' and/or an 'outbreak'. It was also found that COVID-19 is described as highly contagious to everyone who is in contact with an infected person and thus, labelling the virus as "not discriminating". Closer inspection revealed that COVID-19 was mostly described in two salient phrases: 'COVID-19 pandemic' and 'COVID19 outbreak', in which writers used to express certain meanings. These include the description of the crisis in terms of specific times (particularly during the pandemic/outbreak); instances about

\footnotetext{
${ }^{\mathrm{f}}$ It is also interesting to note that the author was later appointed as the new Chairman of Malaysia Digital Economy Corporation (MDEC) for two years, effective June 15 (Retrieved from https://www.nst.com.my/news/nation/2020/06/600121/rais-hussinnamed-new-mdec-chairman). His ideas shared in letters to the editors may not only display his influence or power in the Parti but will now represent his views as Chairman of MDEC, which could be another study worth examining.
} 
the negative impact of the virus and how it has caused for various challenges in the country (most often related to the economy); responses/reactions towards COVID-19 and how the nation deals with it (examples include referring to the Government's responses, the frontliners' contribution and others); and even hopeful messages that were depicted in certain letters reporting about the virus (use of 'legacy' to personify the disease as bringing about a positive lesson for all). It was also important to note that the 'COVID-19 pandemic' is also referred to as the 'coronavirus pandemic', but only in 7 occurrences. So, the name 'coronavirus' in this sense was not found to be as frequent compared to 'COVID-19 pandemic' used in Malaysia. One explanation for this could be in the description of the virus as massive and spreading widely across the world.

This paper has also shown how a corpus-assisted discourse analysis can be carried out on online media discourse about a particular issue. As we hope to have shown, the study begins with a textual analysis of a frequency list of empirically-based selection of salient words occurring more than $50 \%$ of the corpus. We then examined recurring patterns that are measured according to the word's strength of association, which helps us narrow down to significant use of the search term in public letters. The collocational analysis in this part points us to the specific events that are associated to the broader issue under consideration, i.e. COVID-19 and to a certain extent, shows us how writers make links between these so-called events, such as the option for a COVID-19 law that can be very insightful to highlight the political standing of a certain discourse. We have also found recurring mentions of how the virus is portrayed negatively by writers, but the opposite can also be found in more hopeful, uplifting letters. The government and health workers were also portrayed to a certain extent by writers, but in majority recurrences with the salient phrases that were the focus of this paper, representation of these people mentioned could not be significantly determined. Isolated letters like the one by Dr Rais Hussin were only revealed upon further indepth analysis of a frequent use of the phrase in question (e.g. repeated sequence of 'from April till COVID-19 pandemic ends'), which may have been overlooked had it not been for CL techniques.

We have also discovered recurring use of figurative language when it comes to describing COVID-19 as not discriminating its victims, thus rendering the use of this repeated phrase as an important rhetorical role to appeal to readers' emotions. Other metaphorical expressions of the virus were found; particularly those related to war or combat, like comparing COVID-19 to 'World War III' and to 'fight against COVID-19'. In terms of the online letters representing media discourse that is characterised as a discursive process, the strategies in which writers demonstrate their understanding of the issue is different to how discourse analysts investigate media discursive strategies between "source strategies" and media representation. Instead, the present study revealed how letters to the editor represent the public voice on COVID-19 and not the media source (in this case, The Star Online). In our analysis, we look at how Malaysian online letters to the editor describe writers' discourse, but at the same time, we managed to see how social actors within the text are constructed. In their letters to the editor, Malaysians enter into a discourse with other citizens or the readers in general to express their thoughts on the COVID-19 pandemic in their own words. This means that the letters to editors are understood as a mediator of social action, which in turn will represent and construct ideas that inform and/or shape the society. As van Dijk (2005) asserts: "groups who are in control of most influential public discourses, that is symbolic elites such as politicians, journalists, scholars, teachers and writers, play a special role in the reproduction of dominant knowledge and ideologies in society".

The present study extends past work in the field of citizen journalism like Nguyen (2009) and how it shapes social discourse, considering that media discourse has been investigated in terms 
of people in authority, i.e. media agencies. The corpus used in this study on the other hand pays attention to public letters written by citizen journalists that have no trained skills in journalism and hence revealed a much more comprehensive view of public stance on COVID-19 in the Malaysian context. In turn, this highlights the important role of mainstream media such as The Star Online to initiate issues, which will then be amplified via online discussions of its readers. While we have presented the findings as situated or contextualized in terms of the corpus selection -that is, during the first 6 weeks of community-wide containment period in Malaysia - we also contend following van Dijk (2004) that "if contextual analysis should be relevant, it is crucial not only to define possible contexts, but especially to limit them [as well]" (as cited in Carvalho, 2008, p. 163). Ultimately, the paper contributes to the discourse of how Malaysians view and respond to a global crisis such as COVID-19, specifically during a pressing, more stressful time. Further research however, might want to consider how findings may be consistent or changing from past reporting of public issues, particularly ones related to the management of a health crisis that is comparable to the present discussion of COVID-19. Lastly, although findings of this study showed MCO or the Movement Control Order to have significantly co-occurred with the mention of COVID-19, it was not the focus of the in-depth analysis and thus, recommendations include further examination of the relationship between MCO and COVID-19.

\section{REFERENCE}

Arumugam, T. (2020, April 4). MCO-linked domestic violence arises. New Straits Times. Retrieved from https://www.nst.com.my/news/exclusive/2020/04/581233/mco-linkeddomestic-violence-rises

Aziff Azuddin. (2020, April 28). MCO and Mental Well-being: Home Sweet Home? The Centre. Retrieved from https://www.centre.my/post/mco-and-mental-health-living

Baker, P., Gabrielatos, C., KhosraviNik, M., Krzyzanowski, M., McEnery, T., Wodak, R. (2008). A useful methodological synergy? Combining critical discourse analysis and corpus linguistics to examine discourses of refugees and asylum seekers in the UK press. Discourse \& Society (19),pp. 273 - 306.

Bernama. (2020, June 12). Rais Hussin named new MDEC chairman. New Straits Times. Retrieved from https://www.nst.com.my/news/nation/2020/06/600121/rais-hussin-named-newmdec-chairman

Bhagavathula, A. S., Aldhaleei, W. A., Rahmani, J., Mahabadi, M. A., \& Bandari, D. K. (2020). Novel Coronavirus (COVID-19) Knowledge and Perceptions: A Survey of Healthcare Workers. medRxiv preprint https://doi.org/10.1101/2020.03.09.20033381

Burch, B. \& Egbert, J. (2019). Zero-inflated beta distribution applied to word frequency and lexical dispersion in corpus linguistics. Journal of Applied Statistics, 47(2), 1-17.

Burgess, S., \& Sievertsen, H. H. (2020, April 1). Schools, skills, and learning: The impact of COVID-19 on education. Retrieved from https://voxeu.org/article/impact-covid-19education

Brooks, S. K., Webster, R. K., Smith, L. E., Woodland, L., Wessely, S., Greenberg, N., \& Rubin, G. J. (2020). The psychological impact of quarantine and how to reduce it: Rapid review of the evidence. The Lancet, 395, 10227, $912-920$.

Carvalho, A. (2008). Media(ted) discourse and society: Rethinking the framework of critical discourse analysis. Journalism Studies, 9(2): 161-177. 
Collin, L. C. (2019). Corpus Linguistics for Online Communication: A Guide for Research. New York: Routledge

Fairclough, N. (1995). Critical Discourse Analysis. London: Longman.

Fisher, D. \& Wilder-Smith, A. (2020). The global community needs to swiftly ramp up the response to contain COVID-19. Lancet 2020; 395:1109-10.

Gee, J. P. (2011). An introduction to Discourse Analysis: Theory and Method. London and New York: Routledge

Halliday, M. A. K., \& Hasan, R. (1976). Cohesion in English. London: Longman.

Hasimi Muhamad (2020, April 16). 135 domestic violence complaints received throughout MCO. Astro Awani. Retrieved from http://english.astroawani.com/malaysia-news/135-domesticviolence-complaints-received-throughout-mco-238680

Hayek, L., Mayrl, M., \& Russmann, U. (2019). The Citizen as Contributor-Letters to the Editor in the Austrian Tabloid Paper Kronen Zeitung (2008-2017). Journalism Studies, 21(8), pp. 1127-1145. doi:10.1080/1461670x.2019.1702476.

Hellewell, J., Abbott, S., Gimma, A., Bosse, N. I., Jarvis, C. I., Russell, T. W., Munday, J. D., Kucharski, A. J., \& Edmunds, W. J. (2020). Feasibility of controlling COVID-19 outbreaks by isolation of cases and contacts. The Lancet Global Health, 8, 4, e488 - e496.

Hunston, S. (2002). Methods in corpus linguistics: Beyond the concordance line. In S. Hunston (Ed.), Corpora in applied linguistics (pp.67-95). Cambridge: Cambridge University Press.

Loheswar, R. (2020, April 30). More than half of Malaysians experience mental health issues during MCO, study reveals. Malay Mail. Retrieved from https://www.malaymail.com/news/malaysia/2020/04/30/more-than-half-of-malaysiansexperience-mental-health-issues-during-mco-thi/1861634

McNair, B. (2009). Journalism and Democracy. The Handbook of Journalism Studies. New York: Routledge.

Nicola, M., Alsafi, Z., Sohrabi, C., Kerwan, A., Al-Jabir, A., Iosifidis, C., Agha, M., \& Agha, R. (2020). The Socio-Economic Implications of the Coronavirus and COVID-19 Pandemic: A Review. International journal of surgery (London, England), S1743-9191(20)30316-2. Advance online publication. https://doi.org/10.1016/j.ijsu.2020.04.018

Nguyen, A. (2009). Globalization, Citizen Journalism, and the Nation State: A Vietnamese Perspective. In S. Allan \& E. Thorsen (eds.). Citizen Journalism Global Perspectives, pp. 153 - 162. New York: Peter Lang.

Partington, A. (2004). Corpora and Discourse: A Most Congruous Beast. In A. Partington, J. Morley and L. Haarman (eds.). Corpora and Discourse, pp. $11-20$. Bern: Peter Lang.

Partington, A. (2006). Metaphors, Motifs and Similes Across Discourse Types: Corpus assisted Discourse Studies (CADS) at Work. In A. Stefanowitsch and S. Gries (eds.). Corpus-based Approaches to Metaphor and Metonymy, pp. 267 - 304. Berlin: Mouton de Gruyter.

Raeymaeckers, K. (2005). Letter to the Editor: A Feedback Opportunity Turned into a Marketing Tool. European Journal of Communication 20(2), pp.199-221. doi: $10.1177 / 0267323105052298$

Ramanathan, R. \& Tan, B.H. (2015). Application of Discourse Analysis in Media Discourse Studies. 3L: The Southeast Asian Journal of English Language Studies, 21(2), pp. 57 - 68. Scott, M. (2012). WordSmith Tools version 6, Stroud: Lexical Analysis Software.

Sinclair, J. (1991). Corpus, Concordance, Collocation. Oxford: Oxford University Press. 
Singh, L., Bansal, S., Bode, L., Budak, C., Chi, G., Kawintiranon, K., Padden, C., Vanarsdall, R., Vraga, E., \& Wang, Y. (2020). A first look at COVID-19 information and misinformation sharing on Twitter. arXiv e-prints https://arxiv.org/abs/2003.13907

United Nations (March 2020). Shared Responsibility, Global Solidarity: Responding to the socio-economic impacts of COVID-19. Retrieved from https://unsdg.un.org/sites/default/files/2020-03/SG-Report-Socio-Economic-Impact-ofCovid19.pdf

Stubbs, M. (2002). Two Quantitative Methods of Studying Phraseology in English. International Journal of Corpus Linguistics, 7(2), pp. 215 - 244.

United Nations (2020). Everyone Included: Social Impact of COVID-19. Available at https://www.un.org/development/desa/dspd/everyone-included-covid-19.html

van Djik, T. A. (2004). Critical context studies. Universitat Pompeu Fabra, Barcelona. CDA Congress Valencia, May 2004. Retrieved from http://www.discursos.org/unpublished\%20articles/Critical\%20context\%20studies.htm

van Djik, T. A. (2008). Discourse and Power. New York: Palgrave Macmillan.

Wilder-Smith, A. \& Freedman, D. O. (2020). Isolation, quarantine, social distancing and community containment: pivotal role for old-style public health measures in the novel coronavirus (2019-nCoV) outbreak, Journal of Travel Medicine 27, 2, 1 - 4.

Wilson, J. (2020, April 17). The rightwing groups behind wave of protests against Covid-19 restrictions. The Guardian. Retrieved from https://www.theguardian.com/world/2020/apr/17/far-right-coronavirus-protestsrestrictions

Wodak, R. \& Meyer, M. (2009). Critical discourse studies: A sociocognitive approach. In R. Wodak \& M. Meyer (2nd ed). Methods of critical discourse analysis, pp. 62-86. Thousand Oaks: Sage.

World Health Organisation. (2020). Coronavirus disease (COVID-19) Situation Report - 112. Retrieved from https://www.google.com/url?q=https://www.who.int/docs/defaultsource/coronaviruse/situation-reports/20200511-covid-19-sitrep112.pdf?sfvrsn\%3D813f2669 2\&sa=D\&ust=1589296897321000\&usg=AFQjCNFepJon 5McPXrYntLjuNDO5ULXsAg

Zaharom Nain. (2019). Reuters Institute Digital News Report 2019. Available at http://www.digitalnewsreport.org/survey/2018/malaysia-2018/

\section{ABOUT THE AUTHOR}

Siti Aeisha Joharry (Ph.D) is a senior lecturer at the Akademi Pengajian Bahasa, UiTM Shah Alam. Her research interests include corpus linguistics, media discourse and English for professional communication. Recently, her paper "Repetitive bundles in Malaysian learner writing" has been published online in Australian Review of Applied Linguistics. It is available to the current subscribers at: http://doi.org/10.1075/aral.19028.joh

Syamimi Turiman (Ph.D) is a senior lecturer in the Department of English language and Linguistics, Akademi Pengajian Bahasa, UiTM Shah Alam. Her research interests include Corpus Linguistics, Discourse Analysis, and English for Professional Communication. 